\title{
Assessment of Self Perception and Psychiatric Symptoms in Obese Children and Adolescents
}

\section{Obezitesi Olan Çocuk ve Ergenlerde Kendilik Algısı ve Psikiyatrik Belirtilerin Değerlendirilmesi}

\author{
Emel Sarı Gökten ${ }^{1}$, Yeşim Taneli ${ }^{2}$ \\ ${ }^{1}$ Şevket Yılmaz Eğitim Ve Araştırma Hastanesi. Bursa, Çocuk Ve Ergen Psikiyatri Birimi \\ ${ }^{2}$ Uludağ Üniversitesi Tıp Fakültesi, Bursa, Çocuk Ve Ergen Psikiyatri Bölümü
}

Dergiye Ulaşma Tarihi:12/12/2014, Dergiye Kabul Tarihi:29/12/2014, Doi: 10.5505/aot.2014.20592

\begin{abstract}
ÖZET
Amaç: Birçok araştırma obezitesi olan çocuk ve ergenlerde psikopatolojinin daha sık ortaya çıktığını ortaya koymasına rağmen, psikopatolojinin doğası ve boyutu ile ilgili anlaşmazlıklar sürmektedir. Bu araştırma 9 ve 18 yaş arası obezitesi olan çocuk ve ergenlerde kendilik algısı ve psikiyatrik belirtileri araştırmayı amaçlamaktadır. Yöntemler: Çalışmanın örneklemini, Uludağ Üniversitesi Tıp Fakültesi Pediatrik Endokrinoloji Bölümü polikliniğine başvuran 47 obezitesi olan çocuk ve ergen oluşturdu. Psikiyatrik değerlendirme; yarıyapılandırılmış psikiyatrik görüşme, Piers-Harris Çocuklarda Öz-Kavramı Ölçeği, Çocuklar İçin Kovacs Depresyon Ölçeği, Durumluk-Sürekli Kaygı Ölçeği ve Çok Yönlü Beden-Self İlişkisi Ölçeği ile yapıldı. Bulgular: Çalışmaya 47 hasta (26 kız, 21 erkek) alındı. Ortalama yaş 13.1 2.63 tü (9-18). Durumluk anksiyete ortalama puanları daha obez olan grupta yüksekti (BKI $>30 ; p<0,05)$, ancak cinsiyete ya da çocuk-ergen olmaya göre değişmedi $(p>0.05)$. Sürekli anksiyete ve depresyon ortalama puanları ise obezite derecesi, cinsiyet ya da çocuk-ergen farkı gözetmedi ( $\mathrm{p}>0.05)$. Patolojik düzeydeki depresyon, durumluk ve sürekli kaygı oranları obezite derecesi arttıkça, cinsiyete ve çocuk-ergen olmaya göre değişmedi ( $p>0.05)$. Kendilik algısı sonuçları daha obez $(\mathrm{BKI}>30 ; \mathrm{p}<0.05)$ olanların ve ergenlerin $(\mathrm{p}<0.01)$ kendilerini 'daha popüler' gördüklerini gösterdi, kızlar akademik alanda daha pozitif bir kendilik algısına sahipti $(p<0.01)$. Beden-self ilişkisi obezite derecesinin artmasıyla değişmedi ( $p>0.05)$, ancak kılar $(p<0.01)$ ve ergenler $(p<0.05)$ görünüşleriyle daha fazla ilgiliydi, ek olarak kızlar $(\mathrm{p}<0.05)$ sağlık durumlarıyla daha fazla ilgiliydi.

Sonuç: Sonuçlar obezite ile psikopatoloji (depresyon, davranış problemleri, düşük öz-saygı) arasında yüksek ilişki gösteren önceki araştırmalarla uyumlu değildi.
\end{abstract}

Anahtar kelimeler: Obezite; Kendilik algısı; Depresyon; Anksiyete; Beden-self ilişkisi

\begin{abstract}
Objectıve: Although several studies have documented the existence of psychopathology in obese children and adolescents, disagreement remains regarding the extent and nature of this psychopathology. This study aimed to investigate self perception and psychiatric symptoms in obese children and adolescents aged between 9 and 18 years old.

Methods: The study sample consisted of 47 patients admitted to the pediatric endocrinology outpatient clinic at Uludag University School of Medicine. Psychological assessment was performed using a semi-structured psychiatric interview, The Piers-Harris Children's Self-Concept Scale, Kovacs Depression Scale for Children, State-Trait Anxiety Scale, and Multi-Dimensional Body-Self Relations Questionaire.

Results: Fortyseven patients (26 girls and 21 boys) were enrolled in the study. Mean age was $13.1 \pm 2.63$ years (9-18 years). Mean results showed that state anxiety was higher in the more obese $(B M I>30 ; p<0.05)$ but did not differ with sex or being a child or adolescent ( $>0.05)$; and that trait anxiety and depression did not differ for degree of obesity, sex or being a child or adolescent $(\mathrm{p}>0.05)$. Ratio of pathologically high depression, state or trait anxiety did not differ for degree of obesity, sex or being a child or adolescent ( $p>0.05)$. Self-concept results showed that the more obese $(\mathrm{BMI}>30 ; \mathrm{p}<0.05)$ and adolescents $(\mathrm{p}<0.01)$ regarded themselves as more popular, and that girls had a more positive self-concept in the scholastic field $(\mathrm{p}<0.01)$. Body-self relation did not differ by degree of obesity $(p>0.05)$, whereas girls $(p<0.01)$ and adolescents $(p<0.05)$ were more preoccupied with appearance and in addition girls $(\mathrm{p}<0.05)$ were more preoccupied with health.

Conclusion: The results do not support previously published reports which show a higher ratio of psychopathology (depression, behavioral problems, low-esteem) among obese children and adolescents treatment-seeking.
\end{abstract}

Key words: Obesity; Self concept; Depression; Anxiety; Body-self relation. 


\section{Introduction}

Obesity is a major public health problem that causes social, psychological and medical problems (1). The prevalence of obesity is increasing in both developed and developing countries (2,3). Although the prevalence of overweight and obesity varies between different countries and ethnic groups, child and adolescent obesity is one of the major health problems all over the world $(4,5)$.

The study of Third National Health and Nutrition Examination Survey (NHANES III) has shown that the prevalence of obesity between 2 and 19 ages in the United States was $13.7 \%$ among girls and it was $11.7 \%$ among boys (6). Comparison of cross-sectional data from Israel, United States and 13 European countries has shown that the prevalence of overweight, defined as a BMI above the $85^{\text {th }}$ centile and below $95^{\text {th }}$ centile, varied between $5.2 \%$ and $28.9 \%$ for boys and $8.1 \%$ and $31.0 \%$ for girls; the prevalence of obesity defined as a BMI above $95^{\text {th }}$ centile, varied between $1.9 \%$ and $13.9 \%$ for boys and $1.1 \%$ and $15.1 \%$ for girls among adolescents (7). The prevalence of overweight and obesity (excess of the $85^{\text {th }}$ and $95^{\text {th }}$ percentiles) has been found to be $21.1 \%$ and $7.8 \%$ among Iranian adolescents (8), $19.8 \%$ and $7.9 \%$ among Mexican adolescents, $12.1 \%$ and $6.2 \%$ among Egyptian adolescents (9), $15.9 \%$ and $18.4 \%$ among Bahraini adolescents (10) respectively. The prevalence of overweight ranged from $10.3 \%$ to $12.0 \%$ and obesity from $1.6 \%$ to $3.6 \%$ among Turkish adolescents (11-14).

The prevalence of obesity among girls is usually higher than that of boys (6). While the prevalance of overweight is higher among girls in the United Kingdom and United States, it is higher among boys in Italy, Austria and Finland (15).

Although obesity is a prevalent disorder, its social determinants and psychosocial consequences have not yet been fully understood, because obesity is a heterogeneous disorder of multiple aetiology (16). The relationship between self-esteem and obesity was unclear whether self-esteem was consistently related to obesity (17). In general, clinic-based studies have found a relationship between overweight and depression more often than have population-based studies $(10,18)$. In some of the population-based studies, it has been stated that obese children and adolescents (especially girls between 15 and 20) had a higher rate of psychiatric disorder (somatoform disorders, mood disorders, dysesthesia and anxiety disorders) and a lower self image (19).

Previous studies indicated that childhood obesity has psychological consequences such as social interaction problems, depression, low self-esteem, malfunction in attitude to eating, and impulse control disorder (20-23). The objective of this study is to examine how self-reported psychological distress varies based on body weight, gender, and being a child or adolescent among a sample of Turkish children and adolescents. We tested three hypotheses: (a) there is a relationship between weight status and psychological wellbeing, with worse scores among more obese children and adolescents (b) gender difference has an impact on self esteem and psychiatric symptoms for instance obese girls are more affected (c) being a child or an adolescent has different affects on psychological consequences.

\section{Methods}

\section{Study sample}

Obesity was calculated by using body mass index (BMI; individual's weight in kilograms divided by the square of height in meters). Obesity in the study sample was determined using age and sex-spesific norms for BMI. The study sample consisted of children and adolescents with $\mathrm{BMI} \geq 22$ and aged 9-18 years with normal mental capacity and without any chronic physical illness. No subject refused to participate in study. Eleven subjects who have mental retardation and any chronic physical illness, 5 subjects who were younger than 9 years old were excluded. The ethical aspect of the study was approved by Uludag University, School of Medicine and informed consent was obtained from the parents of all subjects. The sample was evaluated with a semi-structured psychiatric interview based on DSM-IV (American Psychiatric Association, 1994) diagnosis of mental disorders by a trained child-adolescent psychiatrist.

\section{Instruments}

Adress for correspondence: Uzm. Dr: Emel Sarı Gökten, Barış Mh. Kubilay Sok. Kırcal Apt. Kat: 4 No: 9 Nilüfer 16130 Bursa - Türkiye 
Piers-Harris Children's Self-Concept Scale (PHCSC), is used to assess self-concept including the following six domains - physical appearance and attributes, freedom from anxiety, intellectual and school status, behavioural adjustment, happiness and satisfaction, and popularity. It is a widely used measure of psychological health in children and adolescents, and has acceptable reliability and validity. The PHCSC scale has been validated for children and adolescents 7 to 18 years of age, is written at a third-grade reading level and contains 80 statements that are answered with a yes or no response. A higher score reflects a more positive response (24). Turkish validation research of the scale was made for children and adolescents 9 to 20 years of age by Catakl1 in 1985 (37).

Kovacs Depression Scale for Children (CDI), a self-rating scale developed by Kovacs, is widely used as a scale for assessment of depression in children and adolescents. It contains 27 likert-type items ranging from 0 to 2 that yield total scores from 0 to 54, where higher scores reflect greater symptomatology. A score of $\geq 19$ is the criterion score for identifying clinical depression (25). Turkish validation research of the scale was made for children 9 to 14 years of age by Oy in 1991 (45).

State-Trait Anxiety Scale (STAI) consists of two, 20-item questionnaires, each measuring a different dimension of anxiety (state anxiety and trait anxiety). The first set of statements (state anxiety) measures how the respondent currently feels. It represents a transitory emotional state that can fluctuate over time and vary in intensity, depending on the situation. The second set of statements (trait-anxiety) assesses how the respondent feels in general, i.e. the individual level of anxiety proneness. This characteristic is considered to be stable over time. Each item is scored on a 4-point intensity scale, with a total score that ranges from 20 to 80 for state-, and the same for trait-anxiety (high scores indicate more severe anxiety) (26). Turkish validation research of the scale was made for adolescents 14 to 18 years of age by Le Compte and Oner in 1985 (46).

Multi-Dimensional Body-Self Relations Questionnaire (MDBRS) is a self-rating scale that consists of 54 items to assess selfattitudinal dimensions of body image including the following 6 domains-appearance

Adress for correspondence: Uzm. Dr: Emel Sarı Gökten, Barış Mh. Kubilay Sok. Kırcal Apt. Kat: 4 No: 9 Nilüfer 16130 Bursa - Türkiye e-mali: esgokten@hotmail.con

Available at www.actaoncologicaturcica.com

Copyright $\mathbb{C}$ Ankara Onkoloji Hastanesi evaluation, appearance orientation, physical competence evaluation, physical competence orientation, health evaluation, health orientation and body satisfaction (27). Turkish validation research of the scale was made for young adults 18 to 25 years of age by Dogan in 1992 (47).

\section{Statistical Analyzes}

Statistical analyzes were performed with Statistical Package for the Social Sciences (version 13.0, SPSSX; SPSS Inc, Chicago, IL, USA). While dependent variables were shown with a mean score \pm standard deviation, independent variables were shown with a number and percentage. Shapiro-Wilk test was performed to find out the relationship between dependent variables and normal distribution, and then Mann Whitney-U test and Double Sampling-Free $t$ test were performed to compare intergroup data. Pearson's Chi-square test and Fisher's Exact Chi-square test were performed to compare independent variables in different groups. Pearson Correlation test was used to assess the correlation between the scores of BMI and the CDI, STAI, PHSCS and MDBRS. The significance level was set at $\mathrm{p}<0.05$; significance levels from 0.05 to 0.10 were defined as a trend.

\section{Results}

Fourty-seven patients between 9 and 18 ages involved in the study, and 26 of them $(55.3 \%)$ were girls while $21(44.7 \%)$ were boys. The mean age of girls was $13.3 \pm 1.82$ (9-18), whereas the mean age of boys was $13.1 \pm 2.63$ (10-16). The mean age of the total group was $13.2 \pm 3.26$. It was seen that gender and age had a significant effect on obesity.

The socio-demografic features of the sample are given in Table 1. Depression was detected in 6 patients, 3 of which were girls and the others were boys. It was also determined that state anxiety of 4 patients in girls and 7 patients in boys was high, while trait anxiety of 11 patients from both groups was high.

The mean scores of depression, state/trait anxiety, self concept and body satisfaction when subjects were divided into two groups as the degree of obesity, gender and being a child or adolescent are given in Table 2. 
Table 1: Socio-demografic features of the sample $(* \mathrm{p}<0.05)$

\begin{tabular}{|c|c|c|c|c|c|c|}
\hline & Female & Female & Male & Male & \multicolumn{2}{|c|}{ Total } \\
\hline & $(\mathrm{n})$ & $\%$ & $(\mathrm{n})$ & $\%$ & (n) & $\%$ \\
\hline \multicolumn{7}{|l|}{ Education status } \\
\hline Primary school & 14 & 29.8 & 19 & 40.4 & 33 & 70.2 \\
\hline High school* & 12 & 25.5 & 2 & 4.3 & 14 & 29.8 \\
\hline Child* & 10 & 21.3 & 16 & 34 & 26 & 55.3 \\
\hline Adolescent* & 16 & 34 & 5 & 10.6 & 21 & 44.7 \\
\hline \multicolumn{7}{|l|}{ Socio-economic status } \\
\hline Lower (421-1000 TL) & 15 & 31.9 & 9 & 19.1 & 24 & 51 \\
\hline Middle (1001-1600 TL) & 9 & 19.1 & 8 & 17 & 17 & 36.2 \\
\hline Upper (>1600 TL) & 2 & 4.3 & 4 & 8.5 & 6 & 12.8 \\
\hline \multicolumn{7}{|l|}{ Residental Background } \\
\hline Urban & 10 & 21.5 & 5 & 10.6 & 15 & 31.9 \\
\hline Suburban & 15 & 31.9 & 16 & 34 & 31 & 66 \\
\hline Rural & 1 & 2.1 & 0 & 0 & 1 & 2.1 \\
\hline \multicolumn{7}{|l|}{$\begin{array}{l}\text { Mother's educational } \\
\text { level }\end{array}$} \\
\hline Uneducated & 1 & 2.1 & 2 & 4.3 & 3 & 6.4 \\
\hline Primary school & 14 & 29.8 & 13 & 27.7 & 27 & 57.4 \\
\hline Secondary school & 2 & 4.3 & 2 & 4.3 & 4 & 8.5 \\
\hline High school & 8 & 17 & 3 & 6.4 & 11 & 23.4 \\
\hline University & 1 & 2.1 & 1 & 2.1 & 2 & 4.3 \\
\hline \multicolumn{7}{|l|}{$\begin{array}{l}\text { Father's educational } \\
\text { level }\end{array}$} \\
\hline Uneducated & 1 & 2.1 & 1 & 2.1 & 2 & 4.3 \\
\hline Primary school & 6 & 12.8 & 8 & 17 & 14 & 29.8 \\
\hline Secondary school & 3 & 6.4 & 3 & 6.4 & 6 & 12.8 \\
\hline High school & 4 & 8.5 & 8 & 17 & 12 & 25.5 \\
\hline University & 12 & 25.5 & 1 & 2.1 & 13 & 27.7 \\
\hline \multicolumn{7}{|l|}{ Mother's occupation } \\
\hline Employee & 2 & 4.3 & 0 & 0 & 2 & 4.3 \\
\hline Officer & 3 & 6.4 & 0 & 0 & 3 & 6.4 \\
\hline Retired & 1 & 2.1 & 1 & 2.1 & 2 & 4.3 \\
\hline Self-employed & 1 & 2.1 & 4 & 8.5 & 5 & 10.6 \\
\hline House-wife & 19 & 40.4 & 16 & 34 & 35 & 74.4 \\
\hline \multicolumn{7}{|l|}{ Father's occupation } \\
\hline Employee & 6 & 12.8 & 7 & 14.9 & 13 & 27.7 \\
\hline Officer & 10 & 21.3 & 2 & 4.3 & 12 & 25.5 \\
\hline Retired & 4 & 8.5 & 5 & 10.6 & 9 & 19.1 \\
\hline Self-employed & 6 & 12.8 & 7 & 14.9 & 13 & 27.7 \\
\hline \multicolumn{7}{|l|}{ Mother's BMI } \\
\hline$<25$ & 3 & 6.4 & 5 & 0.6 & 8 & 17 \\
\hline $25 \leq \mathrm{BMI}<30$ & 9 & 19.1 & 6 & 12.8 & 15 & 31.9 \\
\hline$\geq 30$ & 14 & 29.8 & 10 & 21.3 & 24 & 51.1 \\
\hline \multicolumn{7}{|l|}{ Father's BMI } \\
\hline$<25$ & 1 & 2.1 & 2 & 4.3 & 3 & 6.4 \\
\hline $25 \leq \mathrm{BMI}<30$ & 11 & 23.4 & 11 & 23.4 & 22 & 46.8 \\
\hline$\geq 30$ & 14 & 29.8 & 8 & 17 & 22 & 46.8 \\
\hline
\end{tabular}

\section{Comparison of obese and more obese groups}

Subjects were divided into 2 groups as 30> $\mathrm{BMI} \geq 22$ (obese group) and BMI $\geq 30$ (more obese group). While mean BMI score of the first group was $26.49 \pm 5.39$, it was $32.06 \pm 4.45$ for the other group. Five subjects of obese group had depression while one subject had depression in more obese group. When subjects were evaluated for state/trait anxiety, it was detected that 4 subjects of obese group and 7 subjects of more obese group had higher 
state anxiety score. Likewise, 8 of obese group and 14 of more obese group had higher trait anxiety score. So, it was seen that being more obese did not have a significant effect on depression and state/trait anxiety. However, it was determined that 17 children and 7 adolescents belonged to obese group when children and adolescents were compared.

The mean scores of Kovacs Depression Scale and Trait Anxiety Scale did not show any significant difference between two groups. However, the mean state anxiety score of more obese was significantly higher than that of obese group. There was no statistically significant difference in the mean total scores of the Piers-Harris Children's SelfConcept Scale (PHCSC) between the groups. The mean score of PH3 subscale (popularity) in PHSCS was higher in more obese group. There was no significant difference in the mean total scores of Multi-Dimensional BodySelf Relations Questionnaire (MDBRS) and all its subscales.

There was a moderate but statistically significant correlation between the scores of BMI and state (r: 0.302, p: 0.039) and trait anxiety (r: 0.305 , p: 0.037) in the study sample. There was no correlation between the scores of BMI and depression, self concept or body satisfaction in the study sample.

\section{Comparison of groups for gender}

There was no statistically significant difference in the mean scores of Kovacs Depression Scale and State/Trait Anxiety Scale. But male group showed a higher tendency in state anxiety. There was no significant difference in the mean total scores of The Piers-Harris Children's Self-Concept Scale between groups, while the mean scores of subscales PH6 (intellectual and school status) was higher in female group than male group. There was no significant difference in the mean total scores of Multi-Dimensional Body-Self Relations Questionnaire between groups, while the mean scores of appearance orientation and health orientation were higher in female group than male group.

\section{Comparison of children and adolescent groups}

Subjects involved in the study were accepted as adolescents if females had menstruation and males had sexual dreams. It was seen that 26 patients $(55.3 \%)$ were children (10 girls and 16 boys) and 21 patients $(44.7 \%)$ were adolescents (16 girls and 5 boys). Furthermore, $66.7 \%$ of adolescents and $34.6 \%$ of children had $\mathrm{BMI} \geq 30$.

There was no significant difference in the mean total scores of Kovacs Depression Scale, State/Trait Anxiety Scale, Piers-Harris Children's Self-Concept Scale and MultiDimensional Body-Self Relations Questionnaire between children and adolescent groups. The mean scores of PH3 subscale (popularity) was higher in adolescent group than children group. Furthermore, the mean scores of appearance evaluation were higher in adolescent group.

\section{Discussion}

In this study, among adolescents the number of female subjects were higher while the number of boys were higher among children. However, it was found that most of the subjects were from low or middle socio-economical status. In a study, it was seen that being male and being from higher socio-economical level were predictors of overweight based on BMI (28). Similarly the prevalence of overweight and obesity was found to be higher in boys than in girls in Swedish (29), Canadian (30), Taiwanese (31) and Greek (32) adolescents. Unlike these results, in the studies conducted in adolescent Tehrani and Egyptian students, the prevalence of overweight among girl students was found higher than among boys $(8,9)$. Similarly in a study conducted in a representative sample of schools in the United States, it was found that adolescents from more advantaged family backgrounds (with at least one college-educated parent and a higher family income) were less likely to be overweight (33). In the Mexican and Egyptian adolescents, a higher prevalence of overweight and obesity was found in the highest socioeconomic status in both sexes (9). It was found that being overweight was more frequent in low economic zones in sixth-grade French adolescents (34). In an Australian study, it was found that adolescents of lower socioeconomic status were more likely to be overweight (35). These results suggest that the effects of social factors may be complex and aspects of these effects may vary with cultural features. On the other hand, these findings either suggest that

Adress for correspondence: Uzm. Dr: Emel Sarı Gökten, Barış Mh. Kubilay Sok. Kırcal Apt. Kat: 4 No: 9 Nilüfer 16130 Bursa - Türkiye

e-mali: esgokten@hotmail.com

Available at www.actaoncologicaturcica.com

Copyright $\odot$ Ankara Onkoloji Hastanesi 
Table 2: The mean scores of depression, state/trait anxiety, self concept and body satisfaction when subjects were divided into two groups as the degree of obesity, gender and being a child or adolescent. ( $\mathrm{*} p \leq 0,05$ MS: Mean score SD:Standard deviation)

\begin{tabular}{|c|c|c|c|c|c|c|c|c|c|c|}
\hline \multicolumn{2}{|l|}{ GROUP } & \multirow{2}{*}{$\begin{array}{l}30>\mathrm{BMI} \geq 22 \\
(\mathrm{MS} \pm \mathrm{SD})\end{array}$} & \multirow{2}{*}{\begin{tabular}{|l|}
$\mathrm{BMI} \geq 30$ \\
$(\mathrm{MS} \pm \mathrm{SD})$
\end{tabular}} & \multirow{2}{*}{$\begin{array}{l}\mathrm{p} \\
0,47\end{array}$} & \multirow{2}{*}{$\begin{array}{l}\text { Female } \\
(\mathrm{MS} \pm \mathrm{SD}) \\
29,96 \pm \\
4,42\end{array}$} & \multirow{2}{*}{$\begin{array}{l}\begin{array}{l}\text { Male } \\
(\mathrm{MS} \pm \mathrm{SD})\end{array} \\
30,30 \pm \\
6,48\end{array}$} & \multirow{2}{*}{\begin{tabular}{|l}
$\mathrm{p}$ \\
0,83
\end{tabular}} & \multirow{2}{*}{$\begin{array}{l}\begin{array}{l}\text { Children } \\
(\mathrm{MS} \pm \mathrm{SD})\end{array} \\
29,83 \pm \\
6,14\end{array}$} & \multirow{2}{*}{$\begin{array}{l}\text { Adolescents } \\
\text { (MS } \pm \text { SD) }\end{array}$} & \multirow{2}{*}{$\begin{array}{l}\mathrm{p} \\
0,69\end{array}$} \\
\hline $\begin{array}{l}\text { BMI of } \\
\text { mother }\end{array}$ & & & & & & & & & & \\
\hline $\begin{array}{l}\text { BMI of } \\
\text { father }\end{array}$ & & $28,49 \pm 5,69$ & $\begin{array}{l}31,06 \pm \\
4,36\end{array}$ & 0,15 & $\begin{array}{l}29,53 \pm \\
5,20\end{array}$ & $\begin{array}{l}30,00 \pm \\
5,29\end{array}$ & 0,67 & $\begin{array}{l}30,46 \pm \\
4,84\end{array}$ & $\begin{array}{l}28,85 \pm \\
5,57\end{array}$ & 0,49 \\
\hline Depression & & $10,54 \pm 7,54$ & $\begin{array}{l}10,47 \pm \\
5,48\end{array}$ & 0,78 & $\begin{array}{l}10,34 \pm \\
6,64\end{array}$ & $\begin{array}{l}10,71 \pm \\
6,57\end{array}$ & 0,99 & $\begin{array}{l}10,30 \pm \\
6,72\end{array}$ & $\begin{array}{l}10,76 \pm \\
6,47\end{array}$ & 0,81 \\
\hline 永 & $\begin{array}{l}\text { State } \\
\text { anxiety* }\end{array}$ & $31,96 \pm 9,54$ & $\begin{array}{l}39,92 \pm \\
11,82\end{array}$ & 0,02 & $\begin{array}{l}33,03 \pm \\
8,49\end{array}$ & $\begin{array}{l}39,33 \pm \\
13,51\end{array}$ & 0,058 & $\begin{array}{l}35,38 \pm \\
10,59\end{array}$ & $\begin{array}{l}36,42 \pm \\
12,44\end{array}$ & 0,18 \\
\hline$\underbrace{\tilde{\omega}}_{\tilde{\omega}}$ & $\begin{array}{l}\text { Trait } \\
\text { Anxiety }\end{array}$ & $\begin{array}{l}40,79 \pm \\
9,22\end{array}$ & $\begin{array}{l}45,34 \pm \\
8,68\end{array}$ & 0,51 & $\begin{array}{l}42,65 \pm \\
8,56\end{array}$ & $\begin{array}{l}43,47 \pm \\
10,05\end{array}$ & 0,76 & $\begin{array}{l}42,30 \pm \\
9,44\end{array}$ & $\begin{array}{l}43,90 \pm \\
8,94\end{array}$ & 0,32 \\
\hline \multirow{7}{*}{ 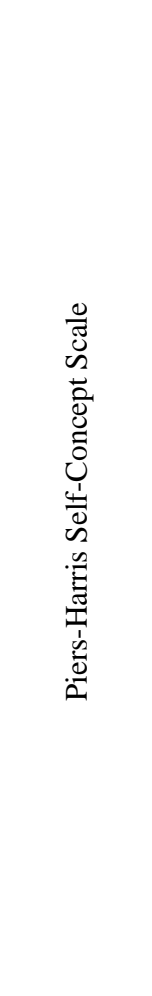 } & Total score & $\begin{array}{l}56,25 \pm \\
12,2\end{array}$ & $\begin{array}{l}56,39 \pm \\
10,97\end{array}$ & 0,8 & $\begin{array}{l}57,38 \pm \\
9,33\end{array}$ & $\begin{array}{l}55,00 \pm \\
13,75\end{array}$ & 0,66 & $\begin{array}{l}55,73 \pm \\
12,56\end{array}$ & $\begin{array}{l}57,04 \pm \\
10,14\end{array}$ & 0,59 \\
\hline & $\begin{array}{l}\text { PH1 } \\
\text { (happiness } \\
\text { and } \\
\text { satisfaction) }\end{array}$ & $9,25 \pm \quad 3,38$ & $\begin{array}{l}9,52 \pm \\
3,04\end{array}$ & 0,9 & $\begin{array}{l}9,34 \pm \\
2,81\end{array}$ & $\begin{array}{l}9,42 \pm \\
3,66\end{array}$ & 0,54 & $\begin{array}{l}9,53 \pm \\
0,28\end{array}$ & $\begin{array}{l}9,19 \pm \\
3,12\end{array}$ & 0,58 \\
\hline & $\begin{array}{l}\mathrm{PH} 2 \\
\text { (freedom } \\
\text { from } \\
\text { anxiety) }\end{array}$ & $6,92 \pm 3,26$ & $\begin{array}{l}6,96 \pm \\
2,93\end{array}$ & 0,57 & $\begin{array}{l}6,38 \pm \\
3,25\end{array}$ & $\begin{array}{l}7,61 \pm \\
2,76\end{array}$ & 0,16 & $\begin{array}{l}7,65 \pm \\
2,92\end{array}$ & $\begin{array}{l}6,04 \pm \\
3,08\end{array}$ & 0,075 \\
\hline & $\begin{array}{l}\text { PH3* } \\
\text { (popularity) }\end{array}$ & $7,96 \pm \quad 2,74$ & $\begin{array}{l}9,30 \pm \\
2,60\end{array}$ & 0,02 & $\begin{array}{l}9,11 \pm \\
2,53\end{array}$ & $\begin{array}{l}8,00 \pm \\
2,89\end{array}$ & 0,09 & $\begin{array}{l}7,76 \pm \\
2,74\end{array}$ & $\begin{array}{l}9,66 \pm \\
2,37\end{array}$ & 0,002 \\
\hline & $\begin{array}{l}\text { PH4 } \\
\text { (behavioural } \\
\text { adjustment) }\end{array}$ & $12,21 \pm 2,76$ & $\begin{array}{l}11,70 \pm \\
2,80\end{array}$ & 0,46 & $\begin{array}{l}11,88 \pm \\
2,55\end{array}$ & $\begin{array}{l}12,04 \pm \\
3,05\end{array}$ & 0,64 & $\begin{array}{l}12,23 \pm \\
2,81\end{array}$ & $\begin{array}{l}11,61 \pm \\
2,71\end{array}$ & 0,37 \\
\hline & $\begin{array}{l}\text { PH5 } \\
\text { (physical } \\
\text { appearance) }\end{array}$ & $6,21 \pm 2,23$ & $\begin{array}{l}6,21 \pm \\
2,09\end{array}$ & 0,79 & $\begin{array}{l}6,50 \pm \\
1,65\end{array}$ & $\begin{array}{l}5,85 \pm \\
2,61\end{array}$ & 0,48 & $\begin{array}{l}5,88 \pm \\
2,35\end{array}$ & $\begin{array}{l}6,61 \pm \\
1,80\end{array}$ & 0,39 \\
\hline & $\begin{array}{l}\text { PH6 (school } \\
\text { status) }\end{array}$ & $4,83 \pm 1,71$ & $\begin{array}{l}4,26 \pm \\
2,26\end{array}$ & 0,48 & $\begin{array}{l}5,30 \pm \\
1,54\end{array}$ & $\begin{array}{l}3,61 \pm \\
2,13\end{array}$ & 0 & $\begin{array}{l}4,30 \pm \\
2,05\end{array}$ & $\begin{array}{l}4,85 \pm \\
1,93\end{array}$ & 0,35 \\
\hline \multicolumn{2}{|c|}{ MDBSR Total Score } & $\begin{array}{l}180,54 \pm \\
26,94\end{array}$ & $\begin{array}{l}178,3 \pm \\
25,65\end{array}$ & 0,65 & $\begin{array}{l}184,03 \pm \\
27,08\end{array}$ & $\begin{array}{l}173,76 \pm \\
24,15\end{array}$ & 0,95 & $\begin{array}{l}175,96 \pm \\
27,81\end{array}$ & $\begin{array}{l}183,76 \pm \\
23,65\end{array}$ & 0,33 \\
\hline
\end{tabular}

thinness is more important for girls than boys in all cultures, and that adolescent boys have a higher risk of being overweight than adolescent girls due to underestimation of body weight, or adolescent girls are more desirous for treatment-seeking than adolescent boys (28). 
In this study, parents of most of the subjects were also obese. Furthermore, mothers of $51 \%$ of the subjects and fathers of $46 \%$ of the subjects had more obese group. The family history of obesity is a predictor of obesity in children because parents play an important role for children in attitude to eating and preferences of food consumption, also genetic factors play a role in aetiology of obesity. Erermis et al. (36) founded that the family history of obesity was $73.3 \%$ in treatment-seeking obese group, $63.4 \%$ in the non-treatment seeking obese group, and $32.4 \%$ among the normal weight controls.

In this study, although all of the subjects were treatment-seeking, depression was found only in 6 patients $(6 / 47,12.77 \%)$ by using Kovacs Depression Scale for Children and psychiatric interviews. 5 subjects in obese group (20.8\%) and only 1 subject in more obese group (4.3\%) had depression. No significant difference was found between the two groups for the mean score of Kovacs Depression Scale for Children. So, it was found that being obese or more obese did not have any effect on having depression in this study. In contrast to our findings, Erermis et al. (36) reported that even though both of treatment-seeking and non-treatment seeking obese groups were more depressed than normal weight control group, the treatment-seeking obese group had higher scores of Kovacs Depression Scale than non-treatment seeking obese group.

The findings about the relationship between obesity and psychopathology are inconsistent in the literature. Meta-analytic studies suggest no significant relationship between obesity and depression in the population (38). Ozmen et al. (28) reported that overweight based on BMI had no effect on self-esteem and depression. Kim \& Kim similarly stated that weight status based on BMI did not help predict the level of selfesteem and depression (39). Wardle et al. also stated that regardless of gender, socioeconomic status or ethnicity, reports of depressive symptoms were not significantly higher in obese than in normal-weight groups (40). Needham \& Crosnoe found that overweight status was related to depressive symptoms among girls and younger adolescents of both genders (33). On the other hand, as mentioned by Fabricatore \& Wadden, obesity may not be systematically associated with psychoAdress for correspondence: Uzm. Dr: Emel Sarı Gökten, Barış Mh. Kubilay Sok. Kırcal Apt. Kat: 4 No: 9 Nilüfer 16130 Bursa - Türkiye e-mali: esgokten@ hotmail.com

Available at www.actaoncologicaturcica.con

Copyright (CAnkara Onkoloji Hastanes pathological conditions (41). There may be some other factors which can mediate the relationship between obesity and psychological distress. There may be multiple patterns of association between obesity-psychopathology or a subgroup of obese adolescents may be an at-risk population. Friedman et al. reported that body-image satisfaction partially mediated the relationship between degree of overweight and depression/self-esteem (42).

In this study, 11 of all subjects $(23.4 \%)$ had high state anxiety level and $22(46.8 \%)$ of all subjects had trait anxiety level by using State/Trait Anxiety Scale and psychiatric interviews. There was only one significant conclusion when the mean scores of state/trait anxiety were compared in all groups. It was that state anxiety of the more obese group was higher than obese group. Erermis et al. (36) reported that the anxiety-depression scores in the Child Behavior Checklist (CBCL) in the clinical obese group were significantly higher than in the non-obese group. On the other hand, Pastore et al. reported that self-esteem and anxiety of obese students did not differ from those of normal weight ones (18).

In this study, there was no significant difference in the mean total scores of The Piers-Harris Children's Self-Concept Scale between all groups. When the subscales of PHCSC were compared, it was seen that the more obese group and adolescents regarded themselves as more popular. In addition, it was found that girls had a more positive selfconcept in the scholastic field, were more preoccupied with appearance and health than boys, and adolescents were more preoccupied with apperance than children. Similarly, Renman et al. have found that obesity had only a minor correlation with self-esteem (43). French et al. reviewed the literature to find out the relationship between self-esteem and obesity, and found that it was unclear whether self-esteem was consistently related to obesity (17). Pesa et al. also stated that body image might explain the low self-esteem of overweight female adolescents (44). Ozmen et al. (28) reported that body dissatisfaction was associated with low self-esteem and depression, and perceived overweight was associated with low self-esteem, but not with depression. On the other hand, actual weight was not associated with low self-esteem and depression. These findings suggested that psychological well-being was more related 
with body satisfaction than actual and perceived weight status.

Adolescents are often concerned with their body image; major concerns include being too short or too tall, being too fat or too thin, perceived defects in bodily apperance, and the presence of acne on the face. The psychological and social burdens of obesity are particularly troublesome for adolescents (36). There are several limitations of the present study findings. First, there was no control groups such as normal weight subjects or obese subjects non-treatment seeking. So, we could not compare our findings with any other group. Second, the number of subjects were insufficient to study the effects of gender on the psychopathology. Third, we did not have any data on psychopathology of the parents. Both psychopathology and obesity are familial

\section{References}

1. Arman AR, Yılmaz S. Obezite ve Çocuk Psikiyatrisi. Ed: Ayla Soykan, Yasemen Taner. Çocuk ve Ergen Ruh Sağlığı ve Hastalıkları. İstanbul Asimetrik Paralel, 2007. 587-603

2. Reilly JJ. Obesity in childhood and adolescence: evidence based clinical and public health perspectives. Postgrad Med J 2006;82:429-37

3. Chinn S, Rona RJ. Prevalence and trends in overweight and obesity in three cross sectional studies of British Children, 1974-94. BMJ 2001;322:24-6

4. Musaiger AO. Overweight and obesity in the Eastern Mediterranean Region: can we control it? East Mediterr Health J 2004;10:789-93

5. Speiser PW, Rudolf MCJ, Anhalt H, CamachoHubner C, Chiarelli F, Eliakim A, et al. Obesity Consensus Working Group: Childhood obesity. J Clin Endocrinol Metab 2005;90:1871-87

6. Styne DM. Childhood and adolescent obesity. Prevalence and significance. Pediatr Clin North Am 2001;48:823-54

7. Lissau I, Overpeck MD, Ruan WJ, Due P, Holstein $\mathrm{BE}$, Hediger ML. Body mass index and overweight in adolescents in 13 European countries, Israle, and United States. Arch Pediatr Adolesc Med 2004; $158: 27-33$

8. Mohammadpour-Ahranjani B, Rashidi A, Karandish M, Eshraghian MR, Kalantari N. Prevalence of overweight and obesity in adolescent Tehrani students, 2000-2001: an epidemic health problem. Public Health Nutr 2004;7:645-8

9. Salazar-Martinez E, Allen B, Fernandez-Ortega C, Torres-Mejia G, Galal O, Lazcano-Ponce E. Overweight and obesity status among adolescents from Mexico and Egypt. Arch Med Res 2006;37:53542 conditions. Data on psychopathology of the parents may enhance an understanding of self concept and psychiatric symptoms in children and adolescents.

\section{Conclusion}

Despite these limitations, the findings of the present study support that psychopathology was not present in all obese children and adolescents. However, both pediatricians and psychiatrists should consider the possibility of psychopathological vulnerability in obese children and adolescents. Clinicians should be more alert on early identification and have aggressive action in the obesity treatment.

\section{Conflict of Interest: None}

10. Al-Sendi AM, Shetty P, Musaiger AO. Body weight perception among Bahraini adolescents. Child Care Health Dev 2004;30:369-76

11. Oner N, Vatansever U, Sari A, and al. Prevalence of underweight, overweight and obesity in Turkish adolescents. Swiss Med Wkly 2004;134:529-33

12. Uckun-Kitapci A, Tezic T, Firat S, et al. Obesity and type 2 diabetes mellitus: a population- based study of adolescents. J Pediatr Endocrinol Metab 2004; 17:1633-40

13. Sur H, Kolotourou M, Dimitriou M, et al. Biochemical and behavioral indices related to BMI in schoolchildren in urban Turkey. Prev Med 2005;41:614-21

14. Krassas GE, Tsametis C, Baleki V, et al. Balkan Group for the Study of Obesity: Prevalence of overweight and obesity among children and adolescents in Thessaloniki-Greece and KayseriTurkey. Pediatr Endocrinol Rev 2004;1(Suppl 3):460-4

15. Parlak A., Çetinkaya Ş. Çocuklarda Obezitenin Oluşumunu Etkileyen Faktörler. Firat Sağlik Hizmetleri Dergisi 2007;5:24-35

16. Wadden TA. Obesity. In Comprehensive Textbook of Psychiatry/VI sixth edition. Edited by: Kaplan HI, Sadock BJ. Baltimore: Williams \& Wilkins; 1995:1481-90

17. French SA, Story M, Perry CL. Self-esteem and obesity in children and adolescents: a literature review. Obes Res 1995;3:479-90

18. Pastore DR, Fisher M, Friedman SB. Abnormalities in weight status, eating attitudes, and eating behaviours among urban high school students correlation with self-esteem and anxiety. J Adolesc Health 1996;18:312-19

19. Buddeberg-Fischer B, Klaghofer R, Reed V. Associations between body weight, psychiatric disorders and body image in female adolescents. Psychother Psychosom 1999;68:325-32

20. Baum CG, Forehand R. Social factors associatedwith adolescent obesity.J Pediatric Psychol 1984;9:293302 
21. Strauss CC, Smith K, Frame C, Forehand R. Personal and interpersonal characteristics associated with childhood obesity. J Pediatric Psychol 1985;10:33743

22. Friedman MA, Brownell KD. Psychological correlates of obesity: moving to the next research generation. Psych Bull 1995;117:3-20

23. Spitzer RL, Stunkard A, Yanovski S. Binge eating disorder should be included in DSM-IV: a reply to Fairburn et al.'s "The classification of recurrent overeating: the binge eating disorder proposal". Int J Eat Disord 1993;13:161-9

24. Öner N. Piers-Harris'in çocuklarda öz-kavramı ölçeği el kitabı. Türk Psikologlar Derneği Kızılay, Ankara, 1996

25. Kovacs M. The Children's Depression Inventory (CDI), Psychopharmacology Bülletin 1981;21:995-8

26. Spielberger CD, Gorsuch RL, Lushene RE. Manual for the state-trait anxiety inventory. California, Consulting Psychologist Press, 1970

27. Cash TF. The multidimensional Body-Self Relations Qestionnaire. (Yayınlanmamış Ölçek El Kitabı). Norfolk, VA, Old Dominion University 1990

28. Özmen D, Özmen E, Ergin D, et al. The association of self-esteem, depression and body satisfaction with obesity among Turkısh adolescents. BMC Public Health 2007;7:80

29. Berg IM, Simonsson B, Brantefors B, Ringqvist I. Prevalence of overweight and obesity in children and adolescents in a county in Sweden. Acta Paediatr 2001;90:671-6

30. Janssen I, Katzmarzyk PT, Boyce WF, King MA, Pickett W. Overweight and obesity in Canadian adolescents and their associations with dietary habits and physical activity patterns. J Adolesc Health 2004;35:360-7

31. Page RM, Lee CM, Miao NF. Assessing prevalence of overweight and obesity through self-reports of height and weight by high school students in Taipe, Taiwan. J Sch Health 2004;74:401-7

32. Karayiannis D, Yannakoulia M, Terzidou M, Sidossis LS, Kokkevi A. Prevalence of overweight and obesity in school-aged children and adolescents. Eur J Clin Nutr 2003;57:1189-92

33. Needham BL, Crosnoe RC. Overweight status and depressive symptoms during adolescence. J Adolesc Health 2005;36:48-55

34. Klein-Platat C, Wagner A, Haan MC, Arveiler D, Schlienger JL, Simon C. Prevalence and sociodemographic determinants of overweight in young French adolescents. Diabetes Metab Res Rev 2003;19:153-8

35. O'Dea JA, Caputi P. Association between socioeconomic status, weight, age and gender, and body image and weight control practices of 6- to 19year-old children and adolescents. Health Educ Res 2001;16:521-32

36. Erermiş S, Çetin N, Tamar M, Bukusoglu N, Akdeniz F, Goksen D. Is obesity a risk factor for psychopathology among adolescents? Pediatrics International 2004;46:296-301

37. Çataklı M. Transliteral equivalance and reliability of the Turkish version of the Piers Harris Children's Self Concept Scale (Yayınlanmamış Yüksek Lisans Tezi). İstanbul: Boğaziçi Üniversitesi; 1985

38. Faith MS, Matz PE, Jorge MA. Obesity-depression associations in the population. J Psychosom Res 2002;53:935-42

39. Kim O, Kim K. Body weight, self-esteem, and depression in Korean Female Adolescents. Adolescence 2001, 36:315-322

40. Wardle J, Williamson S, Johnson F, Edwards C. Depression in adolescent obesity: cultural moderators of the association between obesity and depressive symptoms. Int J Obes (Lond) 2006;30:634-43

41. Fabricatore AN, Wadden TA. Psychological aspects of obesity. Clin Dermatol 2004;22:332-7

42. Friedman KE, Reichmann SK, Costanzo PR, Musante GJ. Body image partially mediates the relationship between obesity and psychological distress. Obes Res 2002;10:33-41

43. Renman C, Engström I, Silfverdal SA, Aman J. Mental health and psychosocial characteristics in adolescents in adolescent obesity: a population-based case control study. Acta Paediatr 1999;88:998-1003

44. Pesa JA, Syre TR, Jones. Psychosocial differences associated with body weight among female adolescents: the importance of body image. J Adolesc Health 2000;26:330-7

45. Öy B. Çocuklar için depresyon ölçeği: Geçerlik ve güvenirlik çalışması. Türk Psikiyatri Dergisi 1991;2:132-7

46. Le Compte A, Öner N. Durumluk-Sürekli Kayg1 Envanteri El Kitabı, İstanbul. Boğaziçi Üniversitesi Yayınları, 1985

47. Doğan O, Doğan S. Çok yönlü beden-self ilişkileri ölçeği el kitabı. Sivas Cumhuriyet Üniversitesi Yayınları, birinci baskı. 1992 